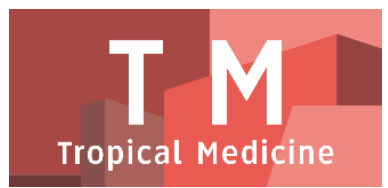

PAPER - OPEN ACCESS

\title{
Pengetahuan Keluarga Tentang Skizofrenia Di Rumah Sakit Jiwa Prof. Dr. Muhammad Ildrem Medan
}

\author{
Author : Ayu Elvany Silaen \\ DOI $\quad: 10.32734 /$ tm.v1i1.48 \\ Paper Page : $18-23$
}

Volume 1 Issue 1 - 2018 TALENTA Conference Series: Tropical Medicine (TM)

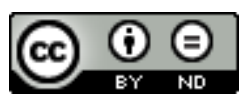

This work is licensed under a Creative Commons Attribution-NoDerivatives 4.0 International License.

Published under licence by TALENTA Publisher, Universitas Sumatera Utara
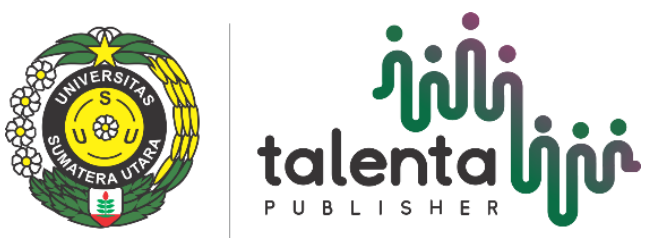


\title{
talentạlo \\ Available online at https://talentaconfseries.usu.ac.id
}

\section{Pengetahuan Keluarga Tentang Skizofrenia Di Rumah Sakit Jiwa Prof. Dr. Muhammad Ildrem Medan}

\author{
Ayu Elvany Silaen ${ }^{\mathrm{a}, *}$, Roxsana Devi Tumanggor ${ }^{\mathrm{a}}$ \\ ${ }^{a}$ Fakultas Keperawatan, Universitas Sumatera Utara, Medan 20155, Indonesia \\ silaen.id@gmail.com, tumanggordevi@gmail.com
}

\begin{abstract}
Abstrak
Schizophrenia is one of mental illness diseases which can decrease individuals' productivity. It becomes a burden for the government, community and the families. Family's participation has important role in recovery process of patients with schizophrenia. In this term, it can be improved through health education program. The aim of this quantitative research was to describe the level of family's knowledge with schizophrenia. The research used accidental sampling technique with 99 respondents. The research instrument was questionnaires on respondents' characteristics and on family's knowledge of schizophrenia. The data were presented with frequency distribution and percentage. The result of the research revealed that 57 respondents $(57.6 \%)$ had good knowledge of schizophrenia, 42 respondents $(42.4 \%)$ had moderate knowledge, and no respondent with poor knowledge. In the last few years, there was the increase in the number of relapse occurance among patients with schizophrenia. Therefore, the high percentage of moderate knowledge was not a real description for the disease. However, nurses were expected to be able to increase family's knowledge by providing health education about schizophrenia. It includes, families understanding about the disease, signs and symptoms, medication management and the families' role in the treatment of patients with schizophrenia.
\end{abstract}

Kata Kunci: Family; Schizophrenia

\section{Pendahuluan}

Skizofrenia atau gangguan jiwa berat merupakan suatu penyakit otak, peristen dan serius yang menyebabkan munculnya gangguan pikiran, persepsi, emosi, gerakan dan perilaku [22]. Skizofrenia bukanlah salah satu penyakit yang mematikan, namun dapat menimbulkan beban bagi pemerintah, masyarakat, serta keluarga dikarenakan produktivitas penderita skizofrenia yang menurun dan biaya pengobatan yang besar [15]. Riset Kesehatan Dasar (Riskesdas) tahun 2013 mencatat bahwa prevalensi gangguan jiwa berat (skizofrenia) sebanyak 1.728 orang yang tersebar di seluruh Indonesia. Kenaikan jumlah penderita gangguan jiwa tersebut umumnya terjadi di sejumlah kota besar. Salah satu Rumah Sakit Jiwa di di kota medan tepatnya di Rumah Sakit Jiwa (RSJ) Prof. Dr. Muhammad Ildrem, menunjukkan pertumbuhan peningkatan kekambuhan skizofrenia dari tahun ke tahun penelitian Sirait (2008) menyatakan bahwa pada tahun 2006-2007 RSJ hanya menerima 25-30 pasien per hari, pada tahun 2008 RSJ menerima 50 orang penderita untuk rawat inap dan sekitar 70-80 orang penderita untuk rawat jalan. Dari survei awal, peneliti memperoleh data di tahun 2015 penderita skizofrenia sebanyak 2.174 orang dan sekitar 90-100 orang penderita untuk rawat jalan [23] Peningkatan jumlah Skizofrenia yang signifikan ini tentunya berdampak pada besarnya biaya pelayanan kesehatan. 
Pada tahun 2009, World Health Organization (WHO) menyarankan agar penanganan kesehatan jiwa, dalam hal ini skizofrenia, lebih ditekankan pada masyarakat terutama keluarga. [1] berpendapat bahwa keluarga adalah suatu sistem, dimana tingkat kesehatan individu berkaitan dengan tingkat kesehatan keluarga. Oleh karena itu, dukungan keluarga menjadi faktor terpenting dalam pencegahan timbulnya kembali gejala-gejala skizofrenia [9]. Karena pada hakikatnya keluarga memiliki tugas di bidang kesehatan [3]. Tugas keluarga dalam kesehatan adalah mengetahui masalah atau defenisi dan tanda gejala skizofrenia, membawa penderita ke petugas kesehatan, merawat penderita, modifikasi lingkungan dan memanfaatkan fasilitas kesehatan yang ada. [9] berpendapat bahwa salah satu permasalahan belum optimalnya penanganan skizofrenia disebabkan ketidaktahuan keluarga terhadap gangguan jiwa maupun skizofrenia. Keluarga yang memiliki pengetahuan kurang mengenai pengobatan skizofrenia sering menyebabkan ketidakpatuhan pasien dalam mengkonsumsi obat [12], Ketidakpatuhan ini kemudian berdampak pada proses pengobatan yang dapat menimbulkan kembali gejala-gejala skizofrenia atau mengalami kekambuhan [2]. Selain itu, pengetahuan seseorang dapat dipengaruhi oleh usia dan tingkat pendidikan, dimana semakin bertambah usia seseorang maka akan semakin berkembang daya tanggap dan pola pikirnya sehingga pengetahuan yang diperoleh semakin baik. Semakin tinggi pendidikan seseorang, maka semakin mudah memperoleh informasi, sehingga memungkinkan semakin banyak pula pengetahuan yang diperoleh [10].

\section{Metode Penelitian}

Penelitian ini merupakan penelitian deskriptif kuantitatif. Tujuan dari penelitian ini adalah mengetahui pengetahuan keluarga tentang skizofrenia berdasarkan usia, jenis kelamin dan pendidikan. Penelitian ini juga bertujuan untuk mengetahui pengetahuan keluarga tentang skizofrenia secara umum. Populasi pada penelitian ini adalah keluarga pasien skizofrenia yang dirawat jalan tahun 2015 di Rumah Sakit Jiwa Prof. Dr. Muhammad Ildrem Medan. Jumlah kunjungan penderita Skizofrenia yang di peroleh dari rekam medis adalah 11.336 orang. Teknik pengambilan sampel dilakukan dengan metode accidental sampling yaitu setiap individu dapat dijadikan sampel tanpa mempertimbangkan karekteristik yang dimiliki oleh individu tersebut. Sehingga didapatkan besar jumlah sampel sebanyak 99 orang. Jumlah sampel ditentukan dengan rumus Slovin dengan tingkat kesalahan yang dipilih adalah 0,1 . Instrumen yang digunakan dalam penelitian ini terdiri dari dua bagian yaitu, data demografi dan pengetahuan keluarga tentang skizofrenia sebanyak 20 item yang terdiri dari empat topik pertanyaan, yaitu; pengertian dan tanda gejala skizofrenia; penggunaan obat; efek samping penggunaan obat; dan peran keluarga dalam merawat penderita skizofrenia. Uji validitas yang digunakan dalam penelitian ini adalah validitas isi dengan nilai 0.83 dan instrumen dinyatakan valid. Uji reabilitas pada penelitian ini dilakukan pada 30 responden. Setelah dilakukan proses perhitungan dengan menggunakan bantuan komputer, diperoleh koefisien 0,809 sehingga instrument penelitian dinyatakan realibel. Pengumpulan data dilakukan setelah mendapat izin dari Dekan Fakultas Keperawatan Universitas Sumatera Utara dan memperoleh ethical clearance dari Komisi Etik Penelitian Kesehatan Fakultas Keperawatan Universitas Sumatera Utara. Selanjutnya peneliti menjelaskan tujuan, manfaat dan prosedur pelaksanaan penelitian kepada calon partisipan dan bila partisipan bersedia berpartisipasi dalam penelitian ini maka partisipan diminta untuk menandatangi surat persetujuan sebagai partisipan (informed consent). Data yang telah terkumpul selanjutnya dianalisa dalam bentuk univarat, yaitu untuk menjelaskan karakeristik masingmasing variabel yang diteliti. 


\section{Hasil Penelitian}

Hasil penelitian ini akan diuraikan dibawah ini dengan mendeskripsikan pengetahuan keluarga berdasarkan umur, jenis kelamin, pendidikan dan pengetahuan keluarga tentang skizofrenia.

Table. 1. Pengetahuan Keluarga Brdasarkan Usia

\begin{tabular}{lcc}
\hline Usia Responden & Pengetahuan & Baik (\%) \\
\hline Dewasa Muda & $10(31.2)$ & $22(68.8)$ \\
Dewasa Tengah & $15(36.6)$ & $26(63.4)$ \\
Dewasa Akhir & $17(42.4)$ & $9(34.6)$ \\
\hline Total & $42(42.4)$ & $57(57.6)$ \\
\hline
\end{tabular}

Hasil penelitian menunjukkan bahwa jumlah total responden yang berusia dewasa tengah sebanyak 41 orang, dewasa awal 32 orang dan usa dewasa akhir 26 orang. Dari tabel tersebut diatas dapat dilihat bahwa sebagian besar responden yang berusia dewasa tengah memiliki pengetahuan yang baik.

Table. 2. Pengetahuan Keluarga Berdasarkan Jenis Kelamin

\begin{tabular}{lcc}
\hline \multirow{2}{*}{ Jenis Kelamin Responden } & Pengetahuan & \\
\hline Laki-laki & Cukup (\%) & Baik (\%) \\
Perempuan & $15(38.5)$ & $24(61.5)$ \\
\hline Total & $27(45.0)$ & $33(55.0)$ \\
\hline
\end{tabular}

Hasil penelitian menunjukkan bahwa jumlah total responden yang berjenis kelamin laki-laki sebanyak 39 orang dan perempuan sebanyak 60 orang.

Table. 3. Pengetahuan Keluarga Berdasarkan Pendidikan

\begin{tabular}{lcc}
\hline & & Pengetahuan \\
Pendidikan Responden & Cukup (\%) & Baik (\%) \\
\hline PT & $5(27.8)$ & $13(72.2)$ \\
SMA & $11(28.9)$ & $27(71.1)$ \\
SMP & $10(47.6)$ & $11(52.4)$ \\
PT & $16(72.7)$ & $6(27.3)$ \\
\hline Total & $42(42.4)$ & $57(57.6)$ \\
\hline
\end{tabular}

Hasil penelitian menunjukkan bahwa jumlah total responden yang berpendidikan SD sebanyak 22 orang, SMP sebanyak 21 orang, SMA sebanyak 38 orang dan PT sebanak 18 orang. Dari tabel tersebut diatas dapat dilihat bahwa sebagian besar responden yang berpendidikan SMA memiliki pengetahuan yang baik. 
Table. 4. Pengetahuan Keluarga Tentang Schizophrenia

\begin{tabular}{lcc}
\hline Pengetahuan Responden & Frekuensi & Persentase \\
\hline Baik & 57 & 57.6 \\
Cukup & 42 & 42.4 \\
Kurang & 0 & 0 \\
\hline
\end{tabular}

\section{Pembahasan}

Pengetahuan keluarga tentang skizofrenia merupakan salah satu faktor yang memiliki nilai yang signifikan terhadap kekambuhan penderita skizofrenia, dimana pengetahuan keluarga tentang skizofrenia yang baik diharapkan dapat mengurangi angka kekambuhan skizofrenia [11].

Hasil dari penelititian ini menunjukkan bahwa sebagian besar responden berusia dewasa tengah, yaitu sebanyak 41 orang. Dari hasil tabulasi silang yang dilakukan jumlah responden yang memiliki pengetahuan baik berdasarkan umur adalah sebanyak 26 orang dan adanya hubungan yang signifikan antara usia dan pengetahuan. Hasil penelitian ini sejalan dengan [24] yang menyatakan bahwa rata-rata usia responden pada penelitian yang dilakukan adalah 42,7 tahun yang mana usia tersebut termaksud dalam kelompok usia dewasa tengah. Kelompok usia dewasa tengah dianggap sudah matang dalam hal mengelolah informasi dan pengetahuan yang diperoleh [20]. Sehingga, semakin bertambah usia seseorang maka semakin bertambah keyakinan mereka untuk datang ke fasilitas kesehatan.

Pada penelitian ini keluarga pasien yang ikut mendampingi penderita ke rumah sakit sebagian besar berjenis kelamin perempuan, yaitu sebanyak 60 orang. Hasi tabulasi silang yang dilakukan menyatakan bahwa tidak adanya hubungan yang signifikan antara pengetahuan dan jenis kelamin. Hasil penelitian ini sejalan dengan hasil penelitian [21] yang menyatakan bahwa mayoritas keluarga yang merawat pasien gangguan jiwa berjenis kelamin perempuan dan Lestari [8] dalam penelitiannya menegaskan bahwa tidak adanya hubungan secara langsung karakteristik jenis kelamin dan pengetahuan seseorang. Sedangkan, Yusnipah [24] berpendapat bahwa pengalaman dan peran keluarga lebih berpengaruh terhadap pengetahuannya.

Hasil penelitian ini menunjukkan bahwa tingkat pendidikan terakhir sebagian besar responden adalah Sekolah Menengah Atas (SMA) yaitu sebanyak 38 orang dan 27 orang diantaranya memiliki pengetahuan yang baik. Hasi tabulasi silang yang dilakukan antara pengetahuan dan pendidikan menyatakan bahwa terdapat hubungan yang signifikan antara pengetahuan dan tingkat pendidikan. Idealnya semakin tinggi pendidikan seseorang maka semakin baik pula pengetahuannya. Hal ini sejalan dengan pernyataan Sari [18] yang menyebutkan bahwa semakin sering seseorang memperoleh informasi maka akan semakin luas wawasan dan pengetahuan seseorang tentang suatu hal.

Hasil penelitian ini juga menunjukkan bahwa sebagian besar responden memiliki pengetahuan yang baik mengenai skizofrenia yaitu 57 orang $(57,6 \%)$ dan 42 orang $(42,4 \%)$ memiliki pengetahuan yang cukup. Peneliti berasumsi bahwa responden sebagian besar sudah mengetahui tentang skizofrenia. Pernyataan tersebut didukung oleh Ryandini [17] bahwa tingkat pengetahuan keluarga pasien skizofrenia sebagian besar adalah tinggi $(55,6 \%)$. Lamanya proses perawatan dan kunjungan rutin ke RSJ untuk kontrol ulang memungkinkan keluarga untuk memperoleh informasi tentang skizofrenia sehingga pengetahuan mereka tentang skizofrenia juga tinggi.

Apabila dilihat dari kriteria pertanyaan yang disampaikan, yakni: pengertian, tanda dan gejala skizofrenia (pertanyaan nomor 1 sampai dengan pertanyaan nomor 5); pengobatan skizofrenia (pertanyaan nomor 6 sampai dengan pertanyaan nomor 10); efek samping penggunaan obat (pertanyaan nomor 11 sampai dengan pertanyaan nomor 15); dan peran keluarga dalam merawat pasien skizofrenia (pertanyaan nomor 16 sampai dengan pertanyaan nomor 20), maka terdapat beberapa pertanyaan yang banyak dijawab salah oleh responden.

Pertanyaan yang paling banyak dijawab salah oleh responden adalah pertanyaan nomor 1 perihal defenisi skizofrenia. Pertanyaan ini dijawab salah oleh responden sebanyak 44 orang $(44,4 \%)$. Pertanyaan tersebut merupakan salah satu pertanyaan apakah keluarga mengetahui masalah kesehatan yang dialami oleh anggota keluarga yang sakit, yang mana salah satu tugas keluarga di bidang kesehatan adalah mengetahui atau mengenal masalah keluarga [3]. Pernyataan tersebut didukung oleh jawaban dari responden terkait pertanyaan nomor 5. Responden sebanyak 57 orang $(57,6 \%)$ menjawab salah tanda dan gejala dari penyakit skizofrenia. Sejalan dengan hasil penelitian Yaqin [23] yang menunjukkan bahwa pengetahuan keluarga tentang tanda dan gejala kekambuhan 
skizofrenia di instansi rawat jalan RSJD Surakarta sebagian besar adalah cukup, serta terdapat hubungan yang signifikan antara pengetahuan tanda dan gejala skizofrenia paranoid dengan upaya mencegah kekambuhan. Responden beranggapan bahwa curiga, marah-marah tanpa sebab dan sering melakukan kekerasan terjadi hanya jika keinginan pasien tidak dipenuhi.

Pertanyaan lainnya yang banyak dijawab salah oleh responden merupakan pertanyaan nomor 8 mengenai cara penggunaan obat dengan persentase $64,4 \%$. Pertanyaan ini dijawab beberapa responden memberikan obat kepada penderita dengan cara menggabungkan dengan pengobatan lain atau pengobatan tradisional yang mereka anggap dapat membantu pemulihan pasien.

Pertanyataan tersebut didukung oleh banyaknya responden yang juga menjawab salah pertanyaan nomor 14 tentang penggunaan dan efek samping obat. Jawaban responden tentang hal ini sebanyak 43orang $(43,4 \%)$ menjawab salah. Padahal pengobatan haruslah tetap diteruskan sesuai dengan anjuran dokter dikarenakan tanda dan gejala dari skizofrenia dapat muncul kembali. Bagi pasien sendiri efek samping obat merupakan salah satu faktor yang mempengaruhi pasien dalam penggunaan obat. Banyak pasien yang menghentikan minum obat dikarenakan terganggu oleh efek samping obat sehingga mempengaruhi tingkat kekambuhan pasien skizofrenia (Kazadi dkk., 2008). Kurnia pada penelitiannya [7] menyatakan bahwa terdapat hubungan bermakna antara keteraturan minum obat dan kekambuhan. Penelitian ini menyatakan bahwa pasien yang tidak teratur minum obat mengalami kekambuhan 31,2\% sedangkan yang tidak kambuh sebesar 3,7\%.

Pertanyaan nomor 16 tentang peran keluarga terhadap penderita skizofrenia juga paling banyak dijawab salah oleh responden adalah pertanyaan. Responden yang berpendapat setuju dengan pertanyaan tersebut adalah sebanyak 60 orang (60,6\%). Artinya, responden menjawab dengan salah. Menurut Hawari pada penelitian [5] skizofrenia dapat mengganggu persepsi, pikiran, pembicaraan, dan gerakan seseorang. Semua aspek aktivitasnya dapat terganggu, bahkan dikalangan masyarakat sering memandang rendah mereka. Pernyataan tersebut sejalan dengan Rakhmat [13] yang menyatakan bahwa keluarga mempunyai pengaruh besar dalam diri kita, dimana kehangatan keluarga dapat menimbulkan perasaan positif. Sesuai dengan pendapat Rasmun [14] yang menyatakan bahwa terdapat beberapa peran keluarga dalam pemulihan skizofrenia. Peran tersebut meliputi melibatkan penderita dalam kegiatan sehari-hari dan kegiatan keluarga, tidak menimbulkan rasa malu terhadap pasien, memberikan rasa peduli dan tanggapan bahwa pasien juga mempunyai fungsi seperti manusia normal umumnya. Sebagai tambahan adalah memberikan pujian atas semua tugas dan kegiatan yang dilakukan pasien untuk merangsang keinginan atau motivasi untuk melakukannya kembali.

Berdasarkan analisa pertanyaan di atas, maka disimpulkan bahwa pengetahuan tentang skizofrenia yang salah memiliki peluang untuk timbulnya kembali kekambuhan pada penderita. Hal tersebut dapat ditinjau dari rekam medis Rumah Sakit Jiwa Prof. Dr. Muhammad Ildream Medan yang mengalami peningkatan penderita skizofrenia setiap tahunnya. Oleh karena itu, pengetahuan tentang skizofrenia sangatlah penting diberikan kepada keluarga.

Peningkatan pengetahuan tentang skizofrenia kepada keluarga dapat dilakukan dengan pemberian pendidikan kesehatan. Haddah [4] menyatahan bahwa pendidikan kesehatan sangat penting untuk meningkatkan status kesehatan dan tingkat pengetahuan baik individu, kelompok, maupun komunitas. Dalam konteks ini meliputi anggota keluarga penderita skizofrenia. Sehingga, dapat mengurangi angka kejadian skizofrenia.

Pendidikan kesehatan bergantung pada hubungan dan komunikasi antara perawat dengan keluarga pasien. Perawat diharapkan dapat meningkatkan pengetahuan dan keterampilan baik pasien maupun keluarga pasien. Oleh sebab itu, seluruh perawat diharapkan mampu menolong pasien dan keluarga dalam meningkatkan pengetahuan mereka melalui pendidikan kesehatan [16].

\section{Kesimpulan}

Pengetahuan keluarga pasien skizofrenia di Rumah Sakit Jiwa Prof. Dr. Muhammad Ildrem Medan adalah baik, hal ini dapat dilihat dari hasil distribusi pengetahuan untuk masing-masing aspek demografi yaitu, usia, jenis kelamin dan pendidikan. Dilihat dari tabulasi silang yang dilakukan maka terdapat hubungan yang signifikan antara usia dan pendidikan terhadap tingkat pengetahuan. Hal tersebut berbeda dengan jenis kelamin, dimana tidak terdapat hubungan yang signifikan antara jenis kelamin dengan pengetahuan seseorang. 


\section{Referensi}

[1] Achjar, K. A. H. (2010) “Aplikasi Praktis Asuhan Keperawatan Keluarga (Cetakan I)”. Jakarta, Sagung Seto

[2] Amelia, D. R \& Anwar, Z. (2013) "Relaps pada Pasien Skizofrenia”. Jurnal ilmiah psikoterapi terapan, 01: 2301-8267.

[3] Friedman, M. (2010) "Keperawatan Keluarga riset, Teori dan Praktik”. Jakarta, EGC

[4] Haddah, M. (2013) "Promoting Mental Health in Men". Journal of Nursing Standart 27 (30): 48-57.

[5] Hawari. (2001) "Pendekatan Holistik Pada Gangguan Jiwa Skizofrenia”. Jakarta, Fakultas Kedokteran Universitas Indonesia.

[6] Kazadi, N.J.B., Moosa, F.Y., Jeenah. (2008) "Factors Associated with Relapse in Psychotic Disorder and Scizophrenia". South African Journal of Psychiatry. 14 (2): 53-62

[7] Kurnia, F. Y. P. (2015) “Analisis Faktor-Faktor yang Mempengaruhi Terjadinya Kekambuhan pada Pasien Skizofrenia di Poli Psikiatri RSD Dr. Soebandi Jember”. Skripsi Fakultas Kedokteran, Universitas Jember, Jember.

[8] Lestari, A. (2011) "Pengaruh Psikoedukasi Keluarga terhadap Pengetahuan dan Tingkat Ansietas Keluarga dalam Merawat Anggota Keluarga yang Mengalami TB di Kota Bandar Lampung". Tesis Fakultas Ilmu Keperawatan, Universitas Indonesia, Jakarta.

[9] Marsaulina, I. (2012) "Pengaruh Dukungan Sosial Keluarga Terhadap Pencegahan Kekambuhan Pasien Skizofrenia yang Berobat Jalan di Badan Layanan Umum Daerah Rumah Sakit Jiwa Medan”. Medan: Repositori USU.

[10] Notoatmodjo, S. (2007) "Promosi Kesehatan dan Ilmu Perilaku". Jakarta, Rineka Cipta

[11]Pratama, Y. \& Syahrial, I. S. (2015) "Hubungan Keluarga Pasien terhadap Kekambuhan Skizofrenia di Badan Layanan Umum Daerah (BLUD) Rumah Sakit Jiwa Aceh”. Jurnal Kedokteran Syiah Kuala (15): 77-86.

[12] Purnamasari, N. Tololiu, T. Pangemanan, H.C. (2013) "Hubungan Pengetahuan Keluarga dengan Kepatuhan Minum Obat Pasien Skizofrenia di Poliklinik Rumah Sakit Prof. V.L. Rmtumbuysang Manado”. Ejournal Keperawatan 1(1): 1-7

[13]Rakhmat, J. (2005) "Psikologi Komunikasi. Bandung”, PT. Remaja Rosdakarya

[14] Rasmun. (2001) “Keperawatan Kesehatan Mental Psikatri Terintegrasi dengan Keluarga”. Jakarta, PT. Fajar Interpratama

[15]Riset Kesehatan Dasar. (2013). Jakarta, Balitbang Kemenkes RI

[16]Ruddick, F. (2013) "Promoting Health and Well-Being”. Journal of Nursing Standart 27 (24): 35-39.

[17] Ryandini, R.F., Saraswati, H.R \& Meikawati, W. (2011) "Faktor-faktor yang Berhubungan dengan Kekambuhan pada Pasien Skizofrenia di Rumah Sakit Jiwa Daerah Dr. Amino Gondohutomo Semarang”. Jurnal keperawatan dan Kebidanan 1 (4), 205-215.

[18] Sari, H. (2009) "Pengaruh Family Psycoeduasi Therapy terhadap Beban dan Kemampuan Keluarga dalam Merawat Klien Pasung di Kelurahan Bireun Nangroe Aceh Darussalam”. Skripsi Fakultas Ilmu Keperawatan, Universitas Indoneia, Jakarta.

[19] Sirait, A. (2008) "Faktor Risiko Terjadinya Relaps pada Pasien Skizofrenia Paranoid". Tesis Magister Kedokteran Klinik, Universitas Sumatera Utara, Medan.

[20] Stuart, G.W \& Laraia. (2005) "Principles and Practice of Psychiatric Nursing". Philadelphia, Elsevier Mosby.

[21] Suwardiman, D. (2011) "Hubungan antara Dukungan Keuarga dengan Regimen Teraupetik pada Keluarga Klien Halusinasi di RSUD Serang”. Skripsi, Fakultas Ilmu Keperawatan Universitas Indonesia, Jakarta.

[22] Videbeck, S. (2008) "Buku Ajar Keperawatan Jiwa”. Jakarta, EGC.

[23] Yaqin, T.F. (2015) "Hubungan Pengetahuan Keluarga tentang Tanda dan Gejala SkizofreniaParanoid dengan Upaya Mencegah Kekambuhan Pasien di RSJD Surakarta”. Skripsi Fakultas Kesehatan Masyarakat, Universitas Muhammadiyah, Surakarta.

[24] Yusnipah, Y. (2012) “Tingkat Pengetahuan Keluarga dalam Merawat Pasien Halusinasi di Poliklinik Psikiatri Rumah Sakit Marzoeki Mahdi Bogor". Skripsi Fakultas Ilmu Keperawatan, Universitas Indonesia, Jakarta. 